\title{
Influence of Calcined Shale on Sulphate Corrosion Resistance of Cement
}

\author{
Jingshun Yuan, Fang Fang, Bin Xue, Xiaohong Cong and Jiangtao Han \\ Hebei Institute of Architecture Civil Engineering, Zhangjiakou 075000, China
}

Keywords: Calcined Shale; Calcination ; Corrosion Resistance Coefficient; Corrosion Mechanism

\begin{abstract}
According to the cement sulfate corrosion resistance properties of Portland cement mixed burning shale to determine the erosion test method, and analyzes the influence of different system of calcined shale sulphate corrosion resistance properties of Portland cement. The results show that: calcined shale during 800 to $900{ }^{\circ} \mathrm{C}, 60 \mathrm{~min} \sim 120 \mathrm{~min}$ mixed into Portland cement, can improve the sulfate resistance of cement resistance in different degree, shale calcined during $850{ }^{\circ} \mathrm{C}$ and $120 \mathrm{~min}$ mixed into Portland cement, corrosion resistance coefficient of cement is 1.25. Through XRD testing means, hydrate of hardened cement paste are analyzed, compared with Portland cement mixed with calcined shale, visible after C-S-H diffraction peaks of cement hydrates phase enhancement, and $\mathrm{Ca}(\mathrm{OH})_{2}$ peak decreased. Using the scanning electron microscope on the part of the corrosion morphology after mortar were observed, visible cement stone in Aft generation, generation of a small amount of Aft to make the structure of cement stone is more compact, beneficial to improve the ability of anti penetration.
\end{abstract}

\section{Introduction}

Portland cement preparated with Portland cement clinker and gypsum has the advantages of high early and later strength , good frost resistance, good wear resistance, but the Portland cement and other admixture is compared, still exists the problem of poor corrosion resistance. One of the main methods to solve the corrosion problem of Portland cement is cement clinker is partial replaced by volcano active substance such as slag or ash etc. In the cement corrosion medium, sources of sulfate corrosion is widely used, including the use of in water, soil, atmosphere, groundwater natural water and industrial may exist potential sulfate corrosion damage, so the development of cement based materials has important practical significance to study the anti sulphate erosion performance. There are many scholars on the base material of cement sulphate corrosion resistance properties were studied by [1-5], mixed active materials such as fly ash, slag, silica fume, bagasse ash, Gu Kanghui replaced parts of Portland cement clinker were improved, sulfate resistance performance of cement based materials.

Zhangjiakou shale of Shangyi county is calcited, and the calcined shale is mixed into Portland cement, the sulphate corrosion resistance ability is tested. And using XRD methods, analysis of the hydration products of cement the phase, morphology of cement mortar corrosion, discusses the influence mechanism of different system of calcined shale resistance to sulfate corrosion on the cement, and provides a basis for improving the performance of sulfate resistance Portland cement using calcined shale.

\section{Test Materials and Process}

Physical properties and chemical composition of portland cement are shown in Table 1, Table 2 respectively. 
Table 1 The physical properties of the portland cement

\begin{tabular}{|c|c|c|c|c|c|}
\hline $\begin{array}{l}\text { Cement } \\
\text { types }\end{array}$ & $\begin{array}{l}\text { Strength } \\
\text { grade }\end{array}$ & $\begin{array}{c}\text { Fineness } \\
\text { Specific surface } \\
\text { area } / \mathrm{m}^{2} \cdot \mathrm{kg}^{-1}\end{array}$ & $\begin{array}{l}\text { Water requirement } \\
\text { for normal consistency }\end{array}$ & $\begin{array}{l}\text { Soundness of } \\
\text { cement }\end{array}$ & $\begin{array}{l}\text { Comressive } \\
\text { strength 28d } \\
\text { fce/MPa }\end{array}$ \\
\hline P. I & 42.5 & 350 & 28.5 & up to standard & 46.0 \\
\hline
\end{tabular}

Table 2 The chemical composition of the portland cement

\begin{tabular}{ccccccrr}
\hline \multirow{2}{*}{$\begin{array}{c}\text { Cement types } \\
\end{array}$} & \multicolumn{7}{c}{ Chemical composition $/ \%$} \\
& loss & $\mathrm{SiO}_{2}$ & $\mathrm{Al}_{2} \mathrm{O}_{3}$ & $\mathrm{Fe}_{2} \mathrm{O}_{3}$ & $\mathrm{CaO}$ & $\mathrm{MgO}^{2}$ \\
\hline $\mathrm{P} . \mathrm{I}$ & 1.44 & 20.98 & 5.03 & 3.06 & 62.76 & 2.52 & 3.38
\end{tabular}

The mixed material chemical composition is shown in Table 3.

Table 3 The chemical composition of the mixing materials

\begin{tabular}{|c|c|c|c|c|c|c|}
\hline \multirow{2}{*}{$\begin{array}{l}\text { The hybrid } \\
\text { materials }\end{array}$} & \multicolumn{6}{|c|}{ The chemical composition /\% } \\
\hline & $\mathrm{SiO}_{2}$ & $\mathrm{Al}_{2} \mathrm{O}_{3}$ & $\mathrm{Fe}_{2} \mathrm{O}_{3}$ & $\mathrm{CaO}$ & $\mathrm{MgO}$ & loss \\
\hline Burn shale & 60.35 & 19.55 & 8.37 & 6.66 & 5.07 & - \\
\hline Fly ash & 50.17 & 31.46 & 5.39 & 5.27 & 0.95 & 1.06 \\
\hline Powder & 36.62 & 12.30 & 1.75 & 33.54 & 6.94 & - \\
\hline \multicolumn{7}{|c|}{$\begin{array}{l}\text { The adoption river sand in the place of Zhang Jia Kou, II the area class go together with and the } \\
\text { class match with a space, the thin degree mold counts to 2.5, medium sand. } \\
\text { The market-available chemistry purely has no water sodium sulfate to try.calcined shale, fly ash, } \\
\text { slag cancined in different firing system are mixed into Portland cement (volume are cement quality } \\
\text { 30\%), and then refer to the GB17671 - } 1999 \text { "cement mortar strength test method (ISO method)" } \\
\text { forming test blocks, test block numbers are listed in Table } 4 \text {. } \\
\text { Table } 4 \text { Sample numbers of cement resistance to corrosion test }\end{array}$} \\
\hline \multirow{2}{*}{$\begin{array}{c}\text { Sample } \\
\text { numbers }\end{array}$} & \multicolumn{2}{|c|}{ Processing conditions } & \multirow{2}{*}{$\begin{array}{l}\text { Sample } \\
\text { numbers }\end{array}$} & \multicolumn{3}{|c|}{ Processing conditions } \\
\hline & $\begin{array}{c}\text { Clcination } \\
\text { temperature/ }\end{array}$ & $\begin{array}{l}\text { Calcination } \\
\text { time/min }\end{array}$ & & & $\begin{array}{ll}\mathrm{n} & \\
\mathrm{a} & { }^{\circ} \mathrm{C}\end{array}$ & $\begin{array}{c}\text { Calcination } \\
\text { time/min }\end{array}$ \\
\hline SU7506 & 750 & 60 & SU9009 & & & 90 \\
\hline SU8006 & 800 & 60 & SU8012 & & & 120 \\
\hline SU8506 & 850 & 60 & SU8015 & & & 150 \\
\hline SU9006 & 900 & 60 & SU8512 & & & 120 \\
\hline SU7509 & 750 & 90 & SU8515 & & & 150 \\
\hline SU8009 & 800 & 90 & SUPF & & & - \\
\hline SU8509 & 850 & 90 & SUPS & & & - \\
\hline
\end{tabular}




\section{Results and Discussion}

\section{Burnt shale on Portland cement sulphate resisting performance influence}

The replacement of Portland cement with different system of calcined shale, the corrosion test, the mortar test block erosion resistance coefficient are calculated with the Ksu, as shown in table 5.

Table 5 Sulphate resistance coefficient of portland burnt shale cement

\begin{tabular}{|c|c|c|c|c|c|c|c|}
\hline \multirow[b]{2}{*}{ Number } & \multicolumn{2}{|c|}{ Bending strength/MPa } & \multirow{2}{*}{$\begin{array}{c}\text { Sulphate } \\
\text { resistance } \\
\text { coefficient t } \\
\text { /Ksu }\end{array}$} & \multirow[b]{2}{*}{ Numbe } & \multicolumn{2}{|c|}{ Bending strength/MPa } & \multirow{2}{*}{$\begin{array}{c}\text { Sulphate } \\
\text { resistance } \\
\text { coefficient } \\
\text { /Ksu }\end{array}$} \\
\hline & $\begin{array}{l}\text { Water } \\
\text { curing }\end{array}$ & $\begin{array}{l}\text { Corrosive liquid } \\
\text { curing }\end{array}$ & & & $\begin{array}{l}\text { Water } \\
\text { curing }\end{array}$ & $\begin{array}{l}\text { Corrosive } \\
\text { liquid curing }\end{array}$ & \\
\hline SU7506 & 7.74 & 7.39 & 0.95 & SU8015 & 7.28 & 8.33 & 1.14 \\
\hline SU 7509 & 7.38 & 7.24 & 0.97 & SU 8506 & 7.65 & 8.74 & 1.14 \\
\hline SU 9006 & 8.17 & 8.55 & 1.05 & SU 8509 & 7.88 & 8.69 & 1.10 \\
\hline SU 9009 & 8.13 & 9.31 & 1.15 & SU8512 & 7.86 & 9.83 & 1.25 \\
\hline SU8006 & 7.21 & 7.49 & 1.04 & SU8515 & 7.91 & 9.75 & 1.23 \\
\hline SU8009 & 7.27 & 7.55 & 1.04 & SUPF & 9.00 & 9.89 & 1.10 \\
\hline SU8012 & 6.76 & 8.03 & 1.18 & SUPS & 8.86 & 9.82 & 1.11 \\
\hline
\end{tabular}

From table 5 comparison, calcined at 750 'ohale (SU75 Series) to improve the Portland cement sulphate corrosion resistance ability is low, the incorporation of the $800{ }^{\circ} \mathrm{C}, 850{ }^{\circ} \mathrm{Cand} 900{ }^{\circ} \mathrm{C}$ calcined shale, corrosion resistance coefficient of cement are improved, especially the SU8512 and SU8515 two groups, anti the corrosion coefficient reaches 1.25 and 1.23 . The corrosion resistance coefficient of slag and fly ash cement were 1.11 and 1.10, it was obvious that most of calcined shale to improve the anti sulfate corrosion properties of Portland cement is better than slag and fly ash.

As shown in Figure 1 rule of anti corrosion coefficient changes with shale calcining time. Under the same temperature, calcination time for $2 \mathrm{~h}$ shale burning can make the Portland cement corrosion resistance reached the highest. While the calcination time under the same conditions, the SU85 series bending corrosion ability is higher than the SU80 series. 


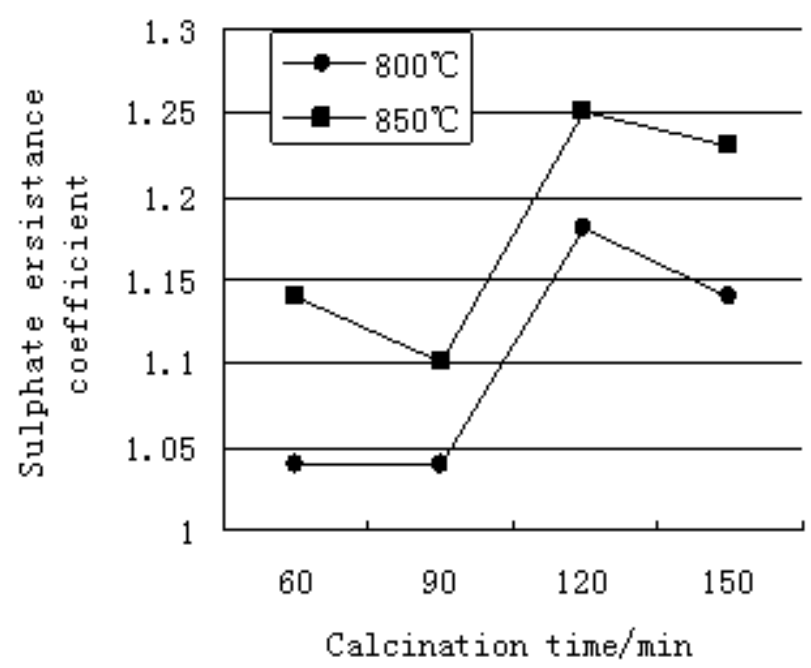

Fig. 1 relationship between sulphate resistance

coefficient and the the calcination system

\section{Burnt shale cement corrosion mechanism}

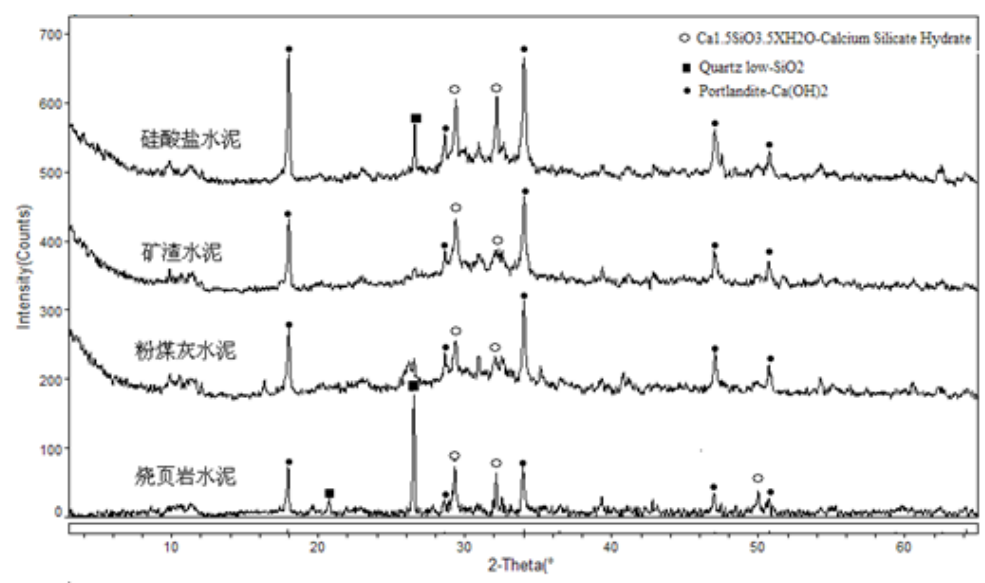

Fig. 2 XRD patterns of 4 kinds of setcement

Burnt shale added to cement, can be consumed in cement hydration products of $\mathrm{Ca}(\mathrm{OH})_{2}$, generating more C-S-H. Figure 2 is the two kind of cement stone, after curing, drying, grinding into powder, XRD diffraction analysis of the pattern . Fig.2 shows the diffraction peak intensity, the difference of the 4 kinds of cement stone is obvious C-S-H, $\mathrm{Ca}(\mathrm{OH})_{2}$, quartz $\left(\mathrm{SiO}_{2}\right), \mathrm{Ca}_{3} \mathrm{Al}_{2}\left(\mathrm{SiO}_{4}\right)$ $(\mathrm{OH})_{8}$ phase. The hardening of Portland cement in the $\mathrm{Ca}(\mathrm{OH})_{2}$ diffraction peaks than the other three kinds of cement is stronger, and burnt shale cement diffraction peaks of C-S-H strong. Combined with the table 3, three kinds of mixed materials, burn $\mathrm{SiO}_{2}$ content in shale hydration reaction at most, therefore, the generated C-S-H will be higher than the other two kinds of cement, water two times product also filled in the slurry in the refinement of capillary pores, pore structure of mortar, cement paste structure and dense because of this, increase the ability of anti permeability, so that the specimen sulfate resistance improved.

\section{Conclusions}

Compared with the above tests, the following conclusions can be drawn:

(1) Corrosion resistance coefficient of glue and sand sample, calcined at $850{ }^{\circ} \mathrm{C}$ and during $120 \mathrm{~min}$, reaches the maximum value 1.25 . 
(2)The incorporation of calcined shale cement hydrates, $\mathrm{Ca}(\mathrm{OH}) 2$ decreased, C-S-H gel increased, which is conducive to improve the ability of anti sulfate corrosion of cement stone.

(3) Shale calcined at $850^{\circ} \mathrm{C}$,duing $60 \sim 120 \mathrm{~min}$ to improve the ability of anti sulfate corrosion of Portland cement is higher than that of fly ash and slag powder.

\section{References}

[1]P.Chindaprasirt, P. Kanchanda, A. Sathonsaowaphak etal. Sulfate resistance of blended cements containing fly ash and rice husk ash[J]. Construction and Building Materials 21 (2007) 13561361.

[2] K.K.Sideris,A.E. Savva, J. Papayianni .Sulfate resistance and carbonation of plain and blended cements[J] Cement \& Concrete Composites 28 (2006) 47-56.

[3]Nuntachai Chusilp,Chai Jaturapitakkul,Kraiwood Kiattikomol. Effects of LOI of ground bagasse ash on the compressive strength and sulfate resistance of mortars[J]. Construction and Building Materials 23 (2009) 3523-3531.

[4] Mansur Sumer .Compressive strength and sulfate resistance properties of concretes containing Class F and Class C fly ashes[J].Construction and Building Materials 34 (2012) 531-536.

[5] Guanghui Zhang. Review on the study of sulfate corrosion of concrete structure [J].

Concrete2012, 267 (1):49-54,61. 